\title{
Retrospective screening of solid organ donors in Italy, 2009, reveals unpredicted circulation of West Nile virus
}

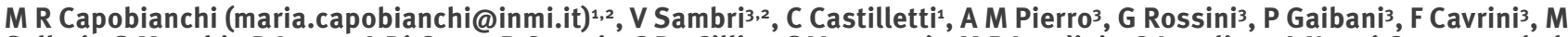

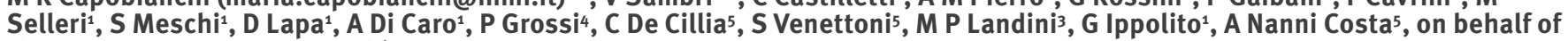
the Italian Transplant Network ${ }^{6}$

1. National Institute for Infectious Diseases (INMI) “L. Spallanzani”, Rome, Italy

2. These authors contributed equally to the work and share first authorship

3. Regional Reference Centre for Microbiological Emergencies (CRREM), Unit of Clinical Microbiology, St Orsola University Hospital, University of Bologna, Bologna, Italy

4. Department of Infectious Diseases, University of Insubria, Varese, Italy

5. National Transplant Centre, Rome, Italy

6. Members are listed at the end of the article

Citation style for this article:

Capobianchi M, Sambri V, Castilletti C, Pierro AM, Rossini G, Gaibani P, Cavrini F, Selleri M, Meschi S, Lapa D, Di Caro A, Grossi P, De Cillia C, Venettoni S, Landin MP, Ippolito G, Nanni Costa A, on behalf of the Italian Transplant Network. Retrospective screening of solid organ donors in Italy, 2009 , reveals unpredicted circulation of West Nile virus. Euro Surveill. 2010;15(34):pii=19648. Available online: http://www.eurosurveillance.org/ViewArticle.aspx?Articleld=19648

Since the occurrence of West Nile virus (WNV) infection in humans in $\mathbf{2 0 0 8}$ in Italy, concerns have been raised about the potential risks associated with solid organ transplantation (SOT). A nationwide retrospective survey showed that $1.2 \%$ of SOT donors in 2009 were WNV-seropositive and demonstrated that human WNV infection is distributed throughout several Italian regions. Transmission of WNV or other arboviruses through SOT is a possibility and risk assessment should be carried out before SOT to avoid infection through transplantation.

\section{Background}

In 1998, when the first cases of equine West Nile virus (WNV) infection in Italy were detected in Tuscany, no human cases were reported [1]. WNV re-emerged in Italy in 2008, and viral circulation was identified among different vectors and different animal species, including horses and wild birds [2]. The first cases of human WNV neuroinvasive infections in Italy were identified in September 2008 in the Emilia-Romagna region [3].

In the summer of 2009, additional human cases were reported in the same and in other neighbouring Italian regions. In one of the most affected areas in the province of Ferrara, a WNV seroprevalence of $0.68 \%$ was observed in healthy blood donors, raising concerns about the potential risks of WNV transmission by blood transfusion and organ transplantation $[4,5]$.

In 2009, as a precautionary measure, the National Transplant Centre issued guidance that potential donations from all donors of solid organs, tissues and cells from the Bologna, Ferrara, Modena and Reggio-Emilia provinces who were screened by nucleic acid amplification tests (NAAT) for the presence of WNV viraemia, and tested positive, had to be rejected. Donors from other regions who had spent at least one overnight stay in the above-listed provinces during the 28 days before donation should not be considered eligible for donation [6].

Two days before screening of donors was implemented, in Bologna, Emilia-Romagna province, transmission of WNV infection through liver transplantation was detected by NAAT before clinical symptoms appeared in the recipient. The transmission of WNV was managed, post-transplant, by administration of hyperimmune serum and viraemia-guided adjustment of the immunosuppressive drug regimen, accompanied by supportive care [7]. The patient recovered from the transplantation and did not develop symptoms of WNV infection or sequelae. Before this case, all reported SOT donor-derived WNV infections were identified retrospectively in symptomatic transplanted patients with severe outcomes in the United States (US) [8]. This post-transplant detection of WNV infection in SOT recipients demonstrates that the absence of a universal screening policy in the immediate pre-transplant period makes it almost impossible to accurately quantify the transmission rate and the subsequent clinical impact of WNV transmission to SOT recipients. In the US, a recent serosurvey carried out among SOT recipients suggested that asymptomatic WNV infection may be common in areas of WNV activity and that the severe clinical presentations of WNV infections are equally frequent in both immunocompromised and immunocompetent subjects [9].

On the basis of this evidence, re-defining the risks for WNV transmission by organ, tissue and cell transplantation was identified by the National Transplant Centre 
as a necessary safety measure before the start of the next WNV season, from late spring to early autumn. The Italian Transplant Network considered this to be a priority in order to establish the factual basis for implementing future strategies for preventing WNV transmission.

A nationwide retrospective survey of WNV seroprevalence was therefore undertaken in all SOT donors recruited by the National Transplant Centre during 2009.

\section{Methods}

Serum samples from the Italian SOT donors in 2009 stored in the biorepository facilities of the Italian Transplant Network, were analysed by the two reference laboratories identified by the National Transplant Centre for assessment of WNV infection: the Laboratory of Virology at the National Institute for Infectious Diseases 'L. Spallanzani' in Rome and the Regional Reference Centre for Microbiological Emergencies of the Microbiology Unit, St Orsola-Malpighi University Hospital, in Bologna.

The presence of WNV-specific IgG and IgM was investigated using a two-step approach: first, a screening test was performed using a commercial enzyme-linked immunosorbent assay (ELISA) method (Euroimmun, $A G$, Lübeck, Germany); all samples that were positive for either IgG or IgM were then confirmed by an immunofluorescent antibody assay (IFA, Euroimmun). Second, the IgG-positive sera were further evaluated by ELISA to measure the IgG avidity, using the method of Fox et al. [10]. All the IgG- and IgM-positive samples identified in the previous steps were further characterised by microneutralisation assay (MNTA) against WNV as previously described [11], and to rule out possible cross-reactions of the test, serum samples were also tested by MNTA against Usutu virus. All IgM-positive sera samples were retrospectively tested by NAAT using Procleix-WNV assay performed on the TIGRIS system, Novartis (for donors from Emilia Romagna) or Artus Real Art WNV LC RT RCRt kit, QIAGEN (for donors from Piedmont and Tuscany) in order to evaluate the presence of WNV viraemia. During the screening activity for WNV in 2009 no WNV-positive donor was identified before SOT.

\section{Results}

A total of 1,248 serum samples from SOT donors in 2009 were analysed, accounting for $98.1 \%$ of SOT donors recruited during that year. Table 1 lists the number of SOT donors evaluated in this study, by region of residence. WNV-specific antibodies were detected in 15 samples from individual donors at the time of organ donation, thus giving an overall positivity rate of $1.2 \%$. Data from MNTA indicate that seven of 15 samples had

TABLE 1

Region of residence of solid organ donors tested for West Nile virus, Italy, 2009 (n=15)

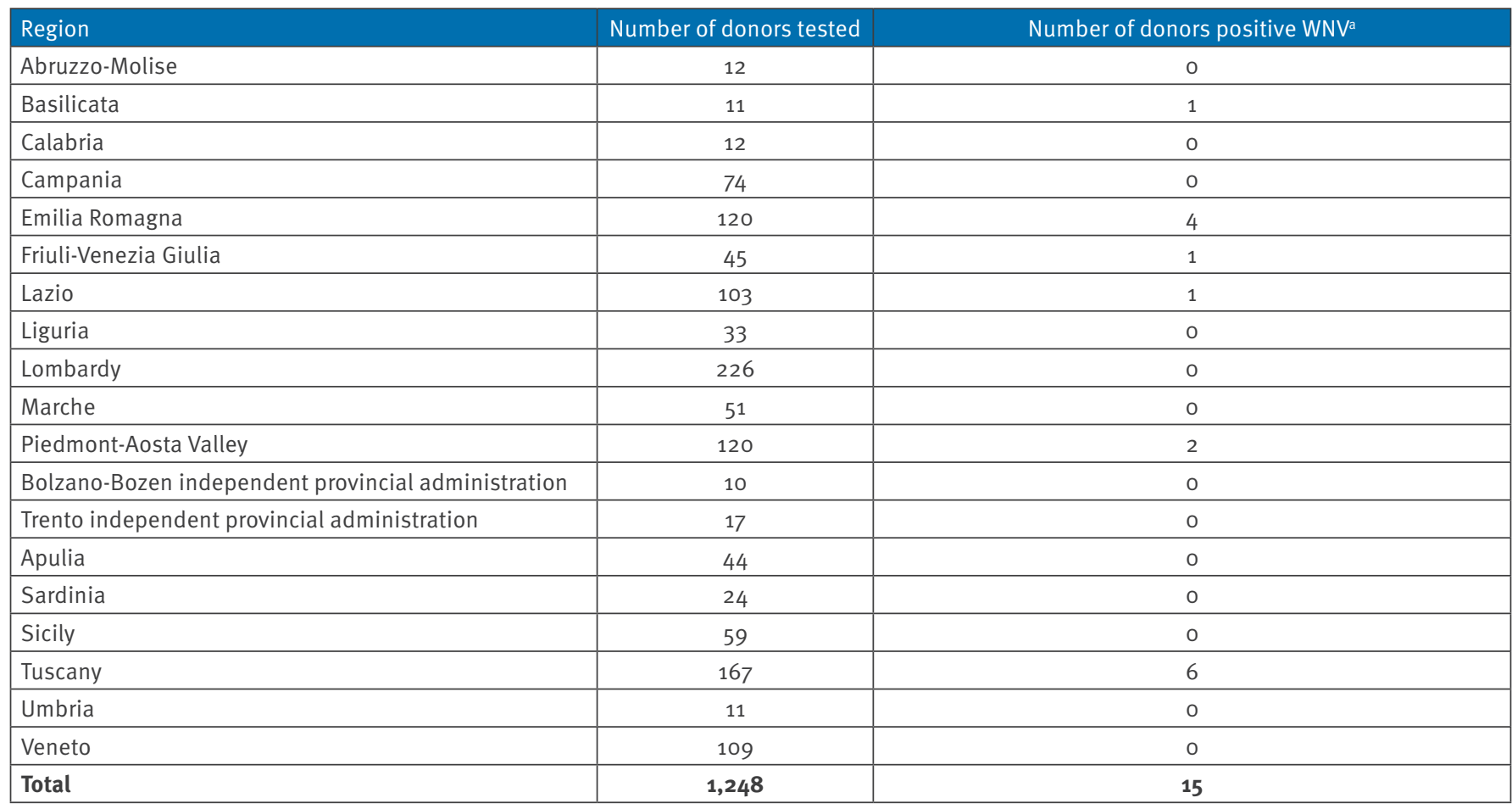

WNV: West Nile virus

${ }^{a}$ IgG - and/or IgM-positive, by serological screening (see Table 2). 
neutralisation activity against WNV. However, eight samples did not show appreciable neutralisation titre against WNV. Among these, two samples were reverse transcription-polymerase chain reaction (RT-PCR) positive and two other samples probably showed neutralisation activity against the related Usutu virus (Table 2).

The inability to confirm by MNTA all the samples testing positive by ELISA and IFA might be due to the cross-reactivity to closely related flaviviruses or might be consistent with the notion that the neutralising response to WNV in humans is variable and that only a subset of infected individuals generate antibodies against high-neutralising epitopes [12]. Furthermore, from a technical point of view, maturation state of WNV particles used in the MNTA might have been important for determining whether antibodies in a given serum samples were judged WNV-specific by MNTA, as already reported by Nelson et al. [13].

The highest number of WNV-seropositive donors were from the regions of Emilia-Romagna and Tuscany (Table 1 and Figure).

Table 2 shows the place of residence, demographic information and laboratory results obtained for these 15 patients.

\section{FIGURE}

Distribution of solid organ donors shown to be positive for West Nile virus ${ }^{\text {a }}$, Italy, $2009(\mathrm{n}=15)$

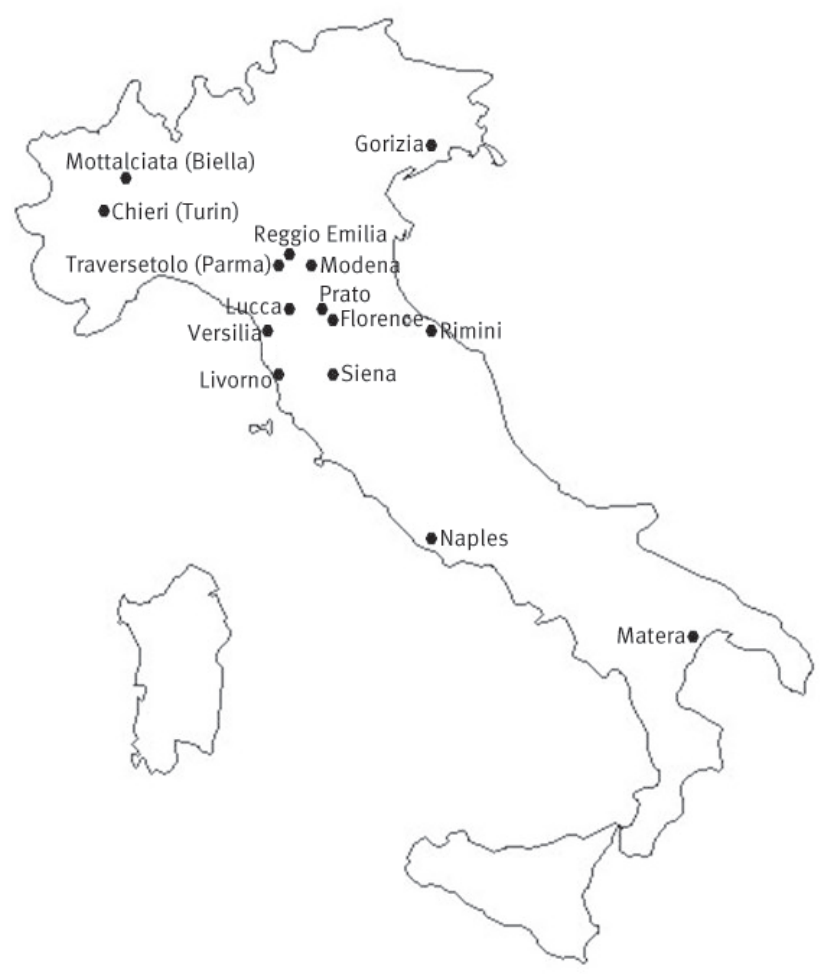

Shown to have West Nile virus-specific antibodies (IgG and/ or (gM) by enzyme-linked immunosorbent assay (ELISA) and immunofluorescent antibody assay (IFA).
Two donors (from Piedmont and Emilia-Romagna) were identified as IgG- and IgM-positive. One donor, from Tuscany, was positive only for IgM. All these three IgM-positive samples were also positive for viral RNA, showing quite a low viral load (equivalent to a genome copy number of $\leq 3 \log$ copies $/ \mathrm{ml}$ ). We speculate that such a low level of viral concentration in blood is likely to pose a limited risk of viral transmission through SOT. Four IgG-positive specimens showed an antibody avidity of $80 \%$ to $90 \%$ suggesting that exposure to WNV probably occurred more than six months before the organ donation; another four IgG-positive samples (all from donors who donated organs after June 2009) showed an antibody avidity lower than $40 \%$, suggesting that the infection was probably acquired within six months before the organ donation, a time frame consistent with WNV exposure during the 2009 mosquito season (June to October).

In addition, recipients of a solid organ from donors who were shown to have been positive for WNV genome or to have had IgM-specific antibodies at the time of organ donation were also included in this study. Two recipients from the Piedmont IgM-positive donor (one kidney recipient and one liver recipient) did not show any seroconversion to WNV. The remaining recipient (who received a kidney) was not available for testing. All three recipients are well and have never shown signs consistent with WNV infection. The IgM-positive donor from Tuscany did not in the end donate organs for reasons not related to WNV infection.

\section{Discussion and conclusions}

The occurrence of an antibody response in some donors from the Piedmont, Friuli-Venezia Giulia, Marche and Basilicata regions is rather unexpected and shows evidence of WNV infection in humans in several Italian regions. However, it is possible that WNV activity has hitherto been underestimated in some regions, due to an insufficient veterinarian and entomological surveillance system, which may have generated inconsistent data. Evidence from the present study - i.e. the low IgG avidity index, the presence of an IgM-specific response and/or WNV RNA in blood samples - is consistent with the notion that recrudescence of WNV activity in Italy occurred in the last two years, following the report of the first human cases of neuroinvasive disease [3-5]. These findings highlights the need for an accurate nationwide approach to risk assessment related to transplantation, in order to implement appropriate prevention strategies and limit the potential burden of severe neurological complications in the immunocompromised recipients. During the 2009 season, only one case of WNV transmission by SOT was observed in the Emilia-Romagna region [7]. No additional cases of WNV transmission from infected donors were documented retrospectively in our study, suggesting that the transmission of WNV to recipients of SOT from viraemic donors does not always occur. Furthermore, 
the positivity in MNTA against Usutu virus in two samples additionally confirms that this virus has to be added to the list of those that can be transmitted to humans $[14,15]$ and its possible transmission through SOT deserves particular attention.

These results indicate that, due to the well-known circulation of WNV in many different areas in Italy, transmission of WNV or other arboviruses through SOT is possible, and that the risk assessment process related to transplantation is a challenging issue that requires a systematic approach [7].

Regional Coordinators of the Italian Transplant Network:

M Scalamogna (Milan); A Famulari (L’Aquila); A Saracino (Matera); B Giacon (Bolzano); P Mancini (Reggio Calabria); E Di Florio (Naples); L Ridolfi (Bologna); R Peressutti (Udine); D Adorno (Roma); A Gianelli Castiglione (Genoa); S Vesconi (Milan); D Testasecca
(Ancona); A Amoroso (Turin); F Paolo Schena (Bari); C Carcassi (Cagliari); V Sparacino (Palermo); R Lippi (Florence); E Gabardi (Trento); C Gambelunghe (Perugia); F Calabrò (Padua).

\section{Acknowledgements}

The work was supported in part by grants to the National Transplant Center and to the National Institute for Infectious Diseases (INMI) (Ricerca Corrente, Ricerca Finalizzata/ Progetto ordinario 2007-9AEF Grant $28 \mathrm{C}_{5} / 3$ ), and to CRREM (Regione Emilia Romagna).

\section{TABLE 2}

Detailed information of solid organ donors who tested positive by serological screening for West Nile virus

\begin{tabular}{|c|c|c|c|c|c|c|c|c|c|}
\hline \multirow{2}{*}{ Region } & \multirow{2}{*}{$\begin{array}{c}\text { Sampling } \\
\text { date, } 2009\end{array}$} & \multirow{2}{*}{ Cause of death } & \multirow{2}{*}{$\begin{array}{l}\text { Age at } \\
\text { death } \\
\text { (years) }\end{array}$} & \multirow{2}{*}{$\begin{array}{l}\text { Place of } \\
\text { residence } \\
\text { (province) }\end{array}$} & \multirow{2}{*}{$\begin{array}{l}\text { Possible place of exposure } \\
\text { (if different from } \\
\text { place of residence) }\end{array}$} & \multicolumn{2}{|c|}{$\begin{array}{l}\text { WNV-specific } \\
\text { antibody titres }\end{array}$} & \multirow{2}{*}{$\begin{array}{l}\lg G \\
\text { avidity } \\
(\%)^{\mathrm{b}}\end{array}$} & \multirow{2}{*}{$\begin{array}{l}\text { MNTA } \\
\text { titre } \\
\text { against } \\
\text { WNV }^{d}\end{array}$} \\
\hline & & & & & & $\lg G$ & $\lg M$ & & \\
\hline Basilicata & 22 Sep & Stroke & 64 & Matera & Lake Garda & $\geq 1: 160$ & $<1: 10$ & 89 & $1: 40$ \\
\hline Lazio & $7 \mathrm{Jul}$ & Stroke & 67 & Rome & - & $1: 80$ & $<1: 10$ & 31 & $1: 40$ \\
\hline Tuscany & $3 \operatorname{Jan}$ & Cranial trauma & 57 & Lucca & - & $1: 80$ & $\langle 1: 10$ & NA & $\langle 1: 10$ \\
\hline Tuscany & 26 Mar & Brain haemorrhage & 67 & $\begin{array}{l}\text { Versilia } \\
\text { (Lucca) }\end{array}$ & - & $1: 40$ & $\ll 1: 10$ & NA & $\ll 1: 10$ \\
\hline Tuscany & $15 \mathrm{Jul}$ & Stroke & 87 & Florence & - & $<1: 10$ & $1: 10^{c}$ & NA & $\ll 1: 10$ \\
\hline Tuscany & 25 Aug & Brain haemorrhage & 74 & Siena & - & $1: 80$ & $\ll 1: 10$ & 11 & $1: 20$ \\
\hline Tuscany & $20 \mathrm{Oct}$ & Brain haemorrhage & 40 & Prato & - & $\geq 1: 160$ & $\ll 1: 10$ & 43 & $<1: 10$ \\
\hline Tuscany & $13 \mathrm{Nov}$ & Cranial trauma & 85 & Livorno & - & $\geq 1: 160$ & $\ll 1: 10$ & 68 & $1: 80$ \\
\hline Piedmont & $28 \mathrm{Jul}$ & Asphyxia/hypoxia & 57 & $\begin{array}{l}\text { Mottalciata } \\
\text { (Biella) }\end{array}$ & - & $1: 80$ & $\ll 1: 10$ & 73 & $\left\langle 1: 10^{\mathrm{e}}\right.$ \\
\hline Piedmont & $21 \mathrm{Oct}$ & Post-anoxic coma & 63 & $\begin{array}{l}\text { Chieri } \\
\text { (Turin) }\end{array}$ & - & $1: 160$ & $1: 40^{c}$ & 13 & $\ll 1: 10$ \\
\hline $\begin{array}{l}\text { Emilia } \\
\text { Romagna } \\
\end{array}$ & 23 Feb & Heart failure & 71 & Modena & - & $1: 400$ & $\ll 1: 10$ & 88 & $1: 80$ \\
\hline $\begin{array}{l}\text { Emilia } \\
\text { Romagna }\end{array}$ & 14 May & Brain haemorrhage & 56 & $\begin{array}{c}\text { Traversetolo } \\
\text { (Parma) }\end{array}$ & - & $1: 200$ & $\ll 1: 10$ & 52 & $\ll 1: 10^{f}$ \\
\hline $\begin{array}{l}\text { Emilia } \\
\text { Romagna }\end{array}$ & 1 Sep & Brain haemorrhage & 78 & Naples & Reggio Emilia & $>1: 1600$ & $1: 80^{c}$ & 25 & $1: 160$ \\
\hline Marche & 1 Aug & Brain haemorrhage & 48 & Rimini & - & $1: 400$ & $\ll 1: 10$ & 84 & $1: 20$ \\
\hline $\begin{array}{l}\text { Friuli- } \\
\text { Venezia } \\
\text { Giulia }\end{array}$ & $24 \mathrm{Jul}$ & $\begin{array}{l}\text { Cranial gunshot } \\
\text { wound }\end{array}$ & 63 & Gorizia & - & $1: 1600$ & $\ll 1: 10$ & 88 & $\ll 1: 10$ \\
\hline
\end{tabular}

MNTA: microneutralisation assay; NA: not applicable, due to low or negative IgG enzyme-linked immunosorbent assay (ELISA) optical density values; WNV: West Nile virus.

a For the donors whose place of residence was not in the WNV activity area identified in 2008 and 2009 , the possible place of WNV exposure was provisionally assigned by a retrospective investigation based on consultation of medical records or on direct information received by the donors' relatives. The dashes $(-)$ in this column indicate that no history of travel in WNV-endemic areas other than those identified in Italy was recorded in the 12 months before donation.

b $\langle 40 \%$ : less than 6 months after infection; >60\%: 6 months or more after infection, according to [10].

c Positive for WNV by reverse transcription-polymerase chain reaction (RT-PCR).

d Samples yielding a neutralisation titre $\geq 1: 20$ were scored as positive.

e MNTA titre against Usutu virus 1:40.

$f$ MNTA titre against Usutu virus 1:80. 


\section{References}

1. Autorino GL, Battisti A, Deubel V, Ferrari G, Forletta R, Giovannini A et al. West Nile virus epidemic in horses, Tuscany region, Italy. Emerg Infect Dis. 2002;8(12):1372-8.

2. Calistri P, Giovannini A, Savini G, et al. West Nile virus transmission in 2008 in north-eastern Italy. Zoonoses Public Health. 2010;57(3):211-9.

3. Rossini G, Cavrini F, Pierro A, Macini P, Finarelli A, Po C et al. First human case of West Nile virus neuroinvasive infection in Italy, September 2008 - case report. Euro Surveill. 2008;13(41). pii=19002. Available from: http://www. eurosurveillance.org/ViewArticle.aspx?Articleld =19002

4. Rizzo C, Vescio F, Declich S, Finarelli AC, Macini P, Mattivi A et al. West Nile virus transmission with human cases in Italy, August - September 2009. Euro Surveill. 2009;14(40). pii: 19353. Available from: http://www.eurosurveillance.org/ ViewArticle.aspx?Articleld $=19353$

5. Grazzini G, Liumbruno GM, Pupella S, Silvestri AR, Randi V, Pascarelli $\mathrm{N}$ et al. West Nile virus in Italy: a further threat to blood safety, a further challenge to the blood system. Blood Transfus. 2008;6(4):235-7.

6. Nanni Costa A, Grossi P, Porta E, Venettoni S, Fehily D. Measures taken to reduce the risk of West Nile virus transmission by transplantation in Italy. Euro Surveill. 2008;13(42). pii: 19009. Available from: http://www. eurosurveillance.org/ViewArticle.aspx?Articleld=19009

7. Morelli MC, Sambri V, Grazi GL, Gaibani P, Pierro A, Cescon M et al. Absence of neuroinvasive disease in a liver transplant recipient who acquired WNV infection from the organ donor and received WNV antibodies prophylactically. Clin Infect Dis. 2010; 51(4):e34-7.

8. Centers for Disease Control and Prevention (CDC). West Nile virus transmission via organ transplantation and blood transfusion - Louisiana, 2008. MMWR Morb Mortal Wkly Rep. 2009;58(45):1263-7.

9. Freifeld AG, Meza J, Schweitzer B, Shafer L, Kalil AC, Sambol AR. Seroprevalence of West Nile virus infection in solid organ transplant recipients. Transpl Infect Dis. 2010;12(2):120-6.

10. Fox JL, Hazell SL, Tobler LH and Busch MP. Immunoglobulin $G$ avidity in differentiation between early and late antibody response to West Nile virus. Clin Vacc Immunol. 2006;13(1):33-6.

11. Monaco F, Lelli R, Teodori L, Pinoni C, Di Gennaro A, Polci A et al. Re-Emergence of West Nile Virus in Italy. Zoonoses Public Health. 2009 Jul 23.

12. Oliphant T, Nybakken GE, Austin SK, Xu Q, Bramson J, Loeb $M$ et al. Induction of epitope-specific neutralizing antibodies against West Nile virus. J Virol. 2007;81(21):11828-39.

13. Nelson S., Jost CA, Xu Q, Ess J, Martin JE, Oliphant T et al. Maturation of West Nile virus modulates sensitivity to antibody-mediated neutralization. PLoS Pathog. 2008;4(5):e1000060.

14. Cavrini F, Gaibani P, Longo G, Pierro AM, Rossini G, Bonilauri $P$ et al. Usutu virus infection in a patient who underwent orthotropic liver transplantation, Italy, August-September 2009. Euro Surveill. 2009 Dec 17;14(50). pii: 19448. Available from: http://www.eurosurveillance.org/ViewArticle. aspx?Articleld $=19448$

15. Pecorari M, Longo G, Gennari W, Grottola A, Sabbatini A, Tagliazucchi S et al. First human case of Usutu virus neuroinvasive infection, Italy, August-September 2009. Euro Surveill. 2009:14(50). pii: 19446. Available from: http://www. eurosurveillance.org/Public/Articles/Archives.aspx 